\title{
Role of midwater chaetognaths in Southern Ocean pelagic energy flow
}

\author{
Svenja Kruse*, Thomas Brey, Ulrich Bathmann
}

Alfred Wegener Institute for Polar and Marine Research, Am Handelshafen 12, 27570 Bremerhaven, Germany

\begin{abstract}
We estimate the energy flow through meso- and bathypelagic chaetognaths in the Atlantic sector of the Southern Ocean from (1) depth-structured chaetognath abundance and body mass data, (2) a general chaetognath respiration model driven by body mass, temperature, water depth and taxon, and (3) published relationships between respiration, production and consumption in chaetognaths. In the 500 to $2000 \mathrm{~m}$ depth layer chaetognaths have a mean biomass of $0.109 \mathrm{mg}$ $\mathrm{C} \mathrm{m}^{-3}$ in summer and $0.146 \mathrm{mg} \mathrm{C} \mathrm{m}^{-3}$ in winter. Chaetognaths respiration and consumption amount to 282 and $563 \mathrm{mg} \mathrm{C} \mathrm{m}^{-2} \mathrm{yr}^{-1}$, respectively. Thus, Antarctic midwater chaetognaths consume $0.05 \%$ of the copepod standing stock per day or $1 \%$ of the daily copepod production in summer. About $2.8 \%$ $\left(=1.9 \mathrm{~g} \mathrm{C} \mathrm{m}^{-2} \mathrm{yr}^{-1}\right)$ of the net annual primary production is required to fuel the midwater chaetognath community via herbivorous copepods. When assuming a 1:1 diet of herbivorous and carnivorous copepods, this share increases to $6.1 \%\left(=4.1 \mathrm{~g} \mathrm{C} \mathrm{m}^{-2} \mathrm{yr}^{-1}\right)$ of annual primary production. It is estimated that chaetognath consumption for the whole water column is $1.4 \mathrm{~g} \mathrm{C} \mathrm{m}^{-2} \mathrm{yr}^{-1}$. This corresponds to $7.1 \%\left(=4.8 \mathrm{~g} \mathrm{C} \mathrm{m}^{-2} \mathrm{yr}^{-1}\right)$ and $15.5 \%\left(=10.4 \mathrm{~g} \mathrm{C} \mathrm{m}^{-2} \mathrm{yr}^{-1}\right)$ of the primary production channeled through herbivorous copepods and through herbivorous and carnivorous copepods, respectively. Hence, chaetognaths represent an important link between lower and higher trophic levels. To further unravel their role in the ecosystem, additional studies on the meso- and bathypelagic zooplankton community are needed.
\end{abstract}

KEY WORDS: Chaetognatha $\cdot$ Antarctica $\cdot$ Midwater $\cdot$ Respiration $\cdot$ Energy budget Resale or republication not permitted without written consent of the publisher

\section{INTRODUCTION}

Chaetognaths are found in all marine habitats, from epipelagic layers to the seafloor. The biomass of these carnivores is estimated to be about $30 \%$ of that of copepods, their principal prey, in the world ocean (Reeve 1970). Antarctic chaetognaths are considered important predators (Pakhomov et al. 1999) and may represent a significant component in the biological carbon pump due to the production of large and fast-sinking fecal pellets (Giesecke et al. 2010). Chaetognath feeding ecology has frequently been studied in terms of gut content analyses, estimates of digestion time and feeding rates (e.g. Øresland 1987, Sameoto 1987, Falkenhaug 1991, Froneman et al. 1998, Giesecke \& González 2004). Several respiration measurements provided information on the chaetognath individual metabolism (e.g. Reeve et al. 1970, Sameoto 1972, Båmstedt 1979, Welch et al. 1996).
However, we know little about the metabolism of Antarctic deep-sea chaetognaths and only a few studies have been conducted to date on individual metabolic activity in Antarctic chaetognaths (Ikeda \& Kirkwood 1989, Kruse et al. 2010).

Evidence suggests that the daily metabolic loss of Antarctic chaetognaths may be lower compared to other chaetognath species at similar temperatures and to other Antarctic zooplankton (Ikeda \& Kirkwood 1989, Kruse et al. 2010). Hence, one might ask whether the overall significance of chaetognaths in the Antarctic pelagic food web, particularly their impact on the copepod community, is also lower. Our current knowledge of the Antarctic meso- and bathypelagic chaetognath community is largely limited, and only some information exists on their taxonomy, abundance and biomass. There are few studies with reasonable resolution in time and space, and most of these are limited 
to the epi- and mesopelagic realm (e.g. Hagen 1985, Terazaki 1989, Duró et al. 1999, Johnson \& Terazaki 2004). The meso- and bathypelagic part of the Antarctic chaetognath community was studied in detail by Kruse et al. (2009) whose findings indicate that Antarctic midwater chaetognaths may constitute a significant vector in pelagic energy flow due to their relatively numerous occurrence.

The present study intends to quantify this ecological impact of Antarctic midwater chaetognaths by combining (1) field data on abundance and body mass with (2) a general chaetognath respiration model derived from published data and own measurements, and (3) published relationships between respiration, production and consumption in chaetognaths.

\section{MATERIALS AND METHODS}

Field sampling. Two expeditions with the RV 'Polarstern' were carried out in the Lazarev Sea during Antarctic winter 2006 (17 June-21 August 2006, expedition ANT 23-6) and Antarctic summer 2007/2008 (28 November 2007-04 February 2008, expedition ANT 24-2). The study area was located between $60-70^{\circ} \mathrm{S}$ and $3^{\circ} \mathrm{W}-3^{\circ} \mathrm{E}$ (see Kruse et al. 2009), except for 2 stations located at $52^{\circ} \mathrm{S} 0^{\circ} \mathrm{E}$ in summer. Samples were taken with a multinet $\left(\mathrm{MN} ; 100 \mu \mathrm{m}\right.$ mesh size, $0.25 \mathrm{~m}^{2}$ mouth area) at 28 stations in winter and at 15 stations in summer. The following standard depth intervals were applied: 2000-1500, 1500-1000, 1000-750, 750-500, 500-0 m. In this study, the 500 to $2000 \mathrm{~m}$ depth range was investigated. For further sampling details see Kruse et al. (2009). A rectangular midwater trawl (RMT 8: $4.5 \mathrm{~mm}$ mesh size, $8 \mathrm{~m}^{2}$ mouth area; RMT 1: $320 \mu \mathrm{m}$ mesh size, $1 \mathrm{~m}^{2}$ mouth area) and a multiple RMT (equipped with three RMT 8 and three RMT 1 nets) were also deployed at a few stations between about $52^{\circ}$ and $64^{\circ} 30^{\prime} \mathrm{S}$ during winter and summer, respectively (Table 1). The RMT stations were selected at positions separated in time and space and at stations where sufficient additional parameters were available from other groups' measurements.

Carbon content. Intact chaetognaths of the 6 species Eukrohnia bathyantarctica, E. bathypelagica, E. hamata, Sagitta gazellae, S. marri and S. maxima were selected from the $\mathrm{MN}$ and RMT samples. The size of the individuals was measured under a stereomicroscope (Olympus SZX12) to the nearest $0.5 \mathrm{~mm}$ (head to tail, excluding tail fin) and immediately frozen at $-80^{\circ} \mathrm{C}$. Upon return to the Alfred Wegener Institute, the chaetognaths were freeze-dried for $24 \mathrm{~h}$ and weighed on Sartorius microbalances. Subsequently, either the carbon content of the entire animal or of subsamples of the ground specimen was determined in a Euro Elemental Analyzer. In total, 584 carbon measurements, 328 from winter and 256 from summer, were made. To analyze seasonal differences in carbon content within each species, the data were Box-Cox transformed when necessary to achieve normality and homogeneity of variances (Sokal \& Rohlf 1981) and subjected to a $t$-test.

Biomass calculation. We tested for differences in carbon content between species by means of analysis of covariance (ANCOVA) (carbon content versus species with body length as covariate) and a subsequent post-hoc Tukey's HSD test on differences between means ( $\alpha=0.05$, Sokal \& Rohlf 1981). Subsequently, we established a multiple linear model of the form:

$$
\begin{aligned}
& \log (C)=a+X_{\text {taxon1 }}+b \times \log (L)+ \\
& X_{\text {taxon2 }} \times\left[\log (L)-L_{\text {mean }}\right]
\end{aligned}
$$

to estimate carbon content $C\left(\mu \mathrm{g}\right.$ ind $\left.^{-1}\right)$ from body length $L(\mathrm{~mm})$, where variables $X_{\text {taxon1 }}$ and $X_{\text {taxon2 }}$ describe the particular effect of each taxon on the relationship between $L$ and $C$. $\log (L)$ is adjusted to mean = 0 in the interaction term $\left(L_{\text {mean }}\right)$ in order to make the test for the main effects independent of the test for interaction ('centered polynomials'). Carbon contents were not differentiated by season.

Community chaetognath biomass $\left(\mu \mathrm{g} \mathrm{C} \mathrm{m}^{-3}\right.$ ) was then calculated from chaetognath length and abundance (Kruse et al. 2009) for each depth interval and station (MN only). A full factorial two-way ANOVA (Biomass vs. Season and Depth, and Season $\times$ Depth) with a subsequent post-hoc test for differences between means was applied to check for effects of season and depth on biomass. Prior to this analysis the data were Box-Cox transformed to achieve normality and homogeneity of variances.

Respiration rate measurements. Respiration rates of Sagitta gazellae (caught by RMT in 500 to 750 m water depth at $64^{\circ} 28.73^{\prime} \mathrm{S} 2^{\circ} 52.24^{\prime} \mathrm{E}$ in summer) were mea-

\begin{tabular}{|c|c|c|c|c|}
\hline Date & Time (UTC) & Latitude & Longitude & Sampling depth (m) \\
\hline \multicolumn{5}{|c|}{ Winter (RMT) } \\
\hline 23.07 .06 & $11: 40$ & $61^{\circ} 58.48^{\prime} \mathrm{S}$ & $0^{\circ} 01.56^{\prime} \mathrm{W}$ & $0-\sim 3000-0$ \\
\hline 10.08 .06 & $15: 18$ & $60^{\circ} 01.31^{\prime} \mathrm{S}$ & $0^{\circ} 00.93^{\prime} \mathrm{W}$ & $0-\sim 3000-0$ \\
\hline 13.08 .06 & $01: 34$ & $59^{\circ} 54.31^{\prime} \mathrm{S}$ & $2^{\circ} 52.70^{\prime} \mathrm{E}$ & $0-\sim 3000-0$ \\
\hline \multicolumn{5}{|c|}{ Summer (multiple RMT) } \\
\hline 03.01 .08 & $07: 36$ & $64^{\circ} 28.73^{\prime} \mathrm{S}$ & $2^{\circ} 52.24^{\prime} \mathrm{E}$ & $500-750-1500-1900$ \\
\hline 21.01 .08 & $10: 45$ & $62^{\circ} 59.88^{\prime} \mathrm{S}$ & $0^{\circ} 01.18^{\prime} \mathrm{E}$ & $500-1000-2000-2500$ \\
\hline 23.01 .08 & 08:03 & $59^{\circ} 59.82^{\prime} \mathrm{S}$ & $0^{\circ} 03.24^{\prime} \mathrm{W}$ & $500-1000-2000-2500$ \\
\hline 26.01 .08 & $11: 51$ & $52^{\circ} 12.08^{\prime} \mathrm{S}$ & $0^{\circ} 00.23^{\prime} \mathrm{E}$ & $0-1000-1500-2000$ \\
\hline
\end{tabular}

Table 1. Southern Ocean stations sampled with rectangular midwater trawl (RMT) 
sured using Winkler titration to determine oxygen concentration as described in Kruse et al. (2010) for Eukrohnia hamata and E. bathypelagica. In contrast to Kruse et al. (2010), 2 unfed specimens of S. gazellae were incubated together in a 11 sealed glass bottle filled with filtered $(0.7 \mu \mathrm{m}$ pore size) and oxygensaturated seawater (saturation of $\sim 96 \%$ ) for $11 \mathrm{~h}$. We conducted one experiment consisting of 5 bottles with chaetognaths and 2 controls without chaetognaths for this species.

Respiration model. To predict chaetognath respiration from body mass, taxon and environmental parameters, we established a multiple linear model of the form:

$\log (R)=a+b_{1} \times \log (M)+b_{2} / T+b_{3} \times \log (D)+X_{\text {taxon }}$

where $R$ is the respiration rate $\left(\mathrm{J} \mathrm{d}^{-1}\right), M$ is the body mass $(\mathrm{J}), T$ is the water temperature $(\mathrm{K}), D$ is the water depth (m), and the variable $X_{\text {taxon }}$ represents a taxonspecific value. This model was fitted using our data on Sagitta gazellae as well as data from Reeve et al. (1970), Nival et al. (1972), Ivleva (1976), Båmstedt (1979), Ikeda (1989), Ikeda \& Kirkwood (1989), Ikeda \& Skjoldal (1989), Thuesen \& Childress (1993), Welch et al. (1996), Ikeda \& Hirakawa (1998), Coston-Clements et al. (2009), and Kruse et al. (2010). The data published by Sameoto (1972) were not used because an a priori analysis showed that these values deviated consistently and significantly from all other sources, indicating a source-specific bias. All data were extracted from the respiration data bank of Brey (2010). Using general factors summarized in Brey (2001) and Brey et al. (2010), the body mass and respiration data of $S$. gazellae were converted to $\mathrm{J}$ and to $\mathrm{J} \mathrm{d}^{-1}$ accordingly. Multivariate outliers in the sample space $[\log (M), 1 / T$, $\log (R)](\alpha=0.05)$ were identified by Mahalanobis Jackknife distances (Barnett \& Price 1995) and excluded from the model construction. Heterokrohnia murina was included in the family Eukrohniidae, because there was only one data point for the family Heterokrohniidae (following the classification of Casanova 1985).

Annual respiration and consumption. The respiration rate $\left(\mathrm{J} \mathrm{d}^{-1}\right)$ of each single individual from all $\mathrm{MN}$ stations during both Antarctic cruises was estimated using the calculated individual chaetognath biomass and the respiration model. From this data base, we inferred the daily chaetognath respiration rate per $\mathrm{m}^{3}$ for both seasons and the annual rate per $\mathrm{m}^{2}$ for the different $\mathrm{MN}$ depth intervals in the investigated area. By means of a full factorial two-way ANOVA (see 'Biomass calculation'; Respiration rate vs. Season and Depth, and Season $\times$ Depth), we tested for seasonal and vertical differences in chaetognath respiration. To achieve normality and homogeneity of variances, the data were Box-Cox transformed prior to this analysis.
We used published data on chaetognath assimilation efficiency (assimilation/consumption) of 0.8 (Cosper \& Reeve 1975, Nagasawa 1985) and gross growth efficiency (production/consumption) of 0.3 (Reeve 1970, Straile 1997) to estimate total chaetognath energy demand ( $\mathrm{g} \mathrm{C} \mathrm{m}^{-2} \mathrm{yr}^{-1}$; $1 \mathrm{~g} \mathrm{C}=45.7 \mathrm{~kJ}$, Salonen et al. 1976). These data indicate that chaetognath consumption $\left(Q_{\text {chaeto }}\right)$ is about twice as high as respiration, i.e.:

$$
Q_{\text {chaeto }}=R_{\text {chaeto }} /(0.8-0.3)
$$

To estimate the amount of primary production $\left(P P_{\text {chaeto }}\right)$ $\left(\mathrm{g} \mathrm{C} \mathrm{m}^{-2} \mathrm{yr}^{-1}\right.$ ) that is required to maintain the chaetognath community through its principal food source, pelagic copepods, we used a copepod gross growth efficiency of 0.3 (Straile 1997, Landry \& Calbet 2004). We assumed that the average chaetognath diet consists either of $100 \%$ herbivorous copepods or of $50 \%$ herbivorous and $50 \%$ carnivorous copepods, as the latter may account for an essential part of the deep living chaetognaths diet:

$$
\begin{gathered}
P P_{\text {chaeto }}=Q_{\text {chaeto }} / 0.3 \text { and } \\
P P_{\text {chaeto }}=0.5 \times Q_{\text {chaeto }} / 0.3+0.5 \times Q_{\text {chaeto }} / 0.3 / 0.3
\end{gathered}
$$

A gross growth efficiency of 0.3 can also be estimated for other zooplankton species. Therefore we assume that the same amount of primary production is needed, even if other zooplankter are constituents of the chaetognath diet.

\section{RESULTS}

\section{Chaetognath biomass}

Body length (ANCOVA, $\mathrm{p}<0.001)$, taxon $(\mathrm{p}<0.001)$ and the interaction between these 2 parameters $(\mathrm{p}<$ 0.001) affect chaetognath carbon content. Test runs with different taxonomic resolution indicated that the separation into the 3 groups Eukrohnia spp., Sagitta marri and other Sagitta spp. generated the best tradeoff between model accuracy and model generality:

$$
\begin{aligned}
& \log (C)=-1.1596+X_{\text {taxon1 }} \\
& +2.9969 \times \log (L)+X_{\text {taxon } 2} \times[\log (L)-1.3898]
\end{aligned}
$$

with $\mathrm{N}=584$ ( 6 species, Table 2$), \mathrm{R}^{2}=0.874$ and $\mathrm{p}<0.001$ for the whole model; $X_{\text {taxon1 }}=+0.0498$ for Eukrohnia spp., +0.1956 for $S$. marri and -0.2454 for Sagitta spp; $X_{\text {taxon2 }}=+0.4756$ for Eukrohnia spp., +0.1283 for $S$. marri and -0.6040 for Sagitta spp. Length-specific carbon content was highest in S. marri, followed by Eukrohnia spp. and Sagitta spp. The latter group includes the large Sagitta species S. gazellae and S. maxima. Hence, we used the $S$. marri parameter values to estimate carbon content of small unidentified Sagitta. 
Based on the abundance data of Kruse et al. (2009), we estimated an average midwater (500 to $2000 \mathrm{~m}$ ) chaetognath biomass of $0.109 \mathrm{mg} \mathrm{C} \mathrm{m}^{-3}$ in summer and $0.146 \mathrm{mg} \mathrm{C} \mathrm{m}^{-3}$ in winter (Table 3 ). The biomass was significantly higher in winter (ANOVA with Tukey's post-hoc test, $\mathrm{p}<0.01$ ) and in the 500 to $750 \mathrm{~m}$ depth range (ANOVA with Tukey's posthoc test, $p<0.001)$. The midwater chaetognath biomass integrated over water depth and averaged over season was $199.9 \mathrm{mg} \mathrm{C} \mathrm{m}^{-2}(\mathrm{SD}=67.2)$.

\section{Respiration model}

Sagitta gazellae respired $0.556 \mu \mathrm{l}$ ind..$^{-1}$ $\mathrm{h}^{-1}(\mathrm{SD}=0.176, \mathrm{~N}=5)$ or $0.011 \mathrm{~J}$ ind..$^{-1}$ $\mathrm{h}^{-1}$. Including these data and the data on Eukrohnia (Kruse et al. 2010), the database for the general chaetognath respiration model consisted of 466 measurements spanning 13 species (3 of them identified to genus only). Mahalanobis distances identified 23 outliers, thereby reducing the data matrix to 443 data sets (Table 4). Trial runs at different taxonomic resolution (species, family, none) indicated that the parameter 'family' provided the best tradeoff between model accuracy and model generality:

$$
\begin{aligned}
& \log (R)=10.0264+0.6643 \times \log (M)- \\
& 2957.8576 / T-0.3870 \times \log (D)+X_{\text {taxon }}
\end{aligned}
$$

Table 2. Carbon content \pm SD (no. of measurements in parentheses) of 6 chaetognath species during summer and winter in the Southern Ocean. DM: dry

\begin{tabular}{|c|c|c|}
\hline \multirow[t]{2}{*}{ Species } & \multicolumn{2}{|c|}{ Carbon content $\left(\mu \mathrm{g} \mathrm{C} \mathrm{mg} \mathrm{DM}^{-1}\right)$} \\
\hline & Summer & Winter \\
\hline Eukrohnia bathyantarctica $^{\text {a }}$ & $324.33 \pm 48.72(42)$ & $424.30 \pm 70.82(35)^{*}$ \\
\hline Eukrohnia bathypelagica ${ }^{\text {a }}$ & $246.23 \pm 72.14(40)$ & $312.96 \pm 89.38(43)^{*}$ \\
\hline Eukrohnia hamata ${ }^{\text {a }}$ & $303.61 \pm 76.53(72)$ & $393.54 \pm 60.99(179)^{*}$ \\
\hline Sagitta gazellae & $319.12 \pm 64.69(40)$ & $274.04 \pm 36.92(27)^{*}$ \\
\hline Sagitta marri & $313.93 \pm 48.17(45)$ & $387.34 \pm 79.40(44)^{*}$ \\
\hline Sagitta maxima & $336.14 \pm 37.42(17)$ & - \\
\hline
\end{tabular}
mass; $(-)$ no data. ${ }^{*} p<0.05$ : significantly different from summer value

Table 3. Biomass (no. of multinet stations in parentheses) and oxygen consumption $\pm \mathrm{SD}$ of chaetognaths at different depth intervals during summer and

\begin{tabular}{|c|c|c|c|c|}
\hline \multirow[t]{2}{*}{$\begin{array}{l}\text { Depth range } \\
\text { (m) }\end{array}$} & \multicolumn{2}{|c|}{$\begin{array}{c}\text { Biomass } \\
\left(\mu \mathrm{C} \mathrm{C} \mathrm{m}^{-3}\right)\end{array}$} & \multicolumn{2}{|c|}{$\begin{array}{l}\text { Oxygen consumption } \\
\left(\mu \mathrm{g} \mathrm{C} \mathrm{m} \mathrm{m}^{-3} \mathrm{~d}^{-1}\right)\end{array}$} \\
\hline & Summer & Winter & Summer & Winter \\
\hline $500-750$ & $250.2 \pm 119.0$ & $268.6 \pm 112.5(28)$ & $1.33 \pm 0.55$ & $1.18 \pm 0.55$ \\
\hline $750-1000$ & $116.4 \pm 56.7(15)$ & $142.9 \pm 104.1(28)$ & $0.50 \pm 0.21$ & $0.58 \pm 0.42$ \\
\hline $1000-1500$ & $57.1 \pm 31.2(15)$ & $118.8 \pm 46.7(27)$ & $0.22 \pm 0.11$ & $0.42 \pm 0.17$ \\
\hline $1500-2000$ & $85.6 \pm 49.6(14)$ & $112.2 \pm 65.0(27)$ & $0.24 \pm 0.08$ & $0.32 \pm 0.15$ \\
\hline $500-2000$ & $109.2 \pm 37.5$ & $145.7 \pm 43.7(27)$ & $0.46 \pm 0.12$ & $0.54 \pm 0.16$ \\
\hline
\end{tabular}
winter in the Southern Ocean (obtained by Eqs. 6 \& 7)

with $\mathrm{N}=443, \mathrm{R}^{2}=0.832$ and $\mathrm{p}<0.001$ for the whole model as well as for each term; with $X_{\text {taxon }}=+0.1212$ for Eukrohniidae and $X_{\text {taxon }}=-0.1212$ for Sagittidae. Respiration per individual generally increases with increasing body mass and rising temperature, and it decreases with increasing depth (Fig. 1). Eukrohniidae have higher rates than Sagittidae. The respiration rates

Table 4. Taxonomic distribution of chaetognath respiration data used for the construction of the general chaetognath respiration

\begin{tabular}{|c|c|c|c|}
\hline Species & Family & $\mathrm{N}$ & Source \\
\hline Caecosagitta macrocephala & Sagittidae & 9 & Thuesen \& Childress (1993) \\
\hline Eukrohnia bathypelagica & Eukrohniidae & 13 & Kruse et al. (2010) \\
\hline Eukrohnia hamata & Eukrohniidae & 96 & Båmstedt (1979), Kruse et al. (2010) \\
\hline Eukrohnia spp. (E. hamata, E. fowleri) & Eukrohniidae & 11 & Thuesen \& Childress (1993) \\
\hline Flaccisagitta hexaptera & Sagittidae & 1 & Thuesen \& Childress (1993) \\
\hline Heterokrohnia murina & Heterokrohniidae & 1 & Thuesen \& Childress (1993) \\
\hline Parasagitta elegans ${ }^{\mathrm{a}}$ & Sagittidae & 77 & Welch et al. (1996) \\
\hline Pseudosagitta spp. (P. lyra, P. maxima) & Sagittidae & 15 & Thuesen \& Childress (1993) \\
\hline Sagitta elegans ${ }^{\mathrm{a}}$ & Sagittidae & 16 & $\begin{array}{l}\text { Båmstedt (1979), Ikeda (1989), Ikeda \& Kirkwood (1989) } \\
\text { Ikeda \& Skjoldal (1989), Ikeda \& Hirakawa (1998) }\end{array}$ \\
\hline Sagitta gazellae & Sagittidae & 43 & Ikeda (1989), Ikeda \& Kirkwood (1989), present study \\
\hline Sagitta hispida & Sagittidae & 26 & Reeve et al. (1970) \\
\hline Sagitta tenuis & Sagittidae & 15 & Coston-Clements et al. (2009) \\
\hline Sagitta spp. & Sagittidae & 108 & Ivleva (1976), Thuesen \& Childress (1993) \\
\hline Solidosagitta zetesios & Sagittidae & 12 & Thuesen \& Childress (1993) \\
\hline Total & & 443 & \\
\hline
\end{tabular}
model (reduced by 23 outliers). N: number of data 


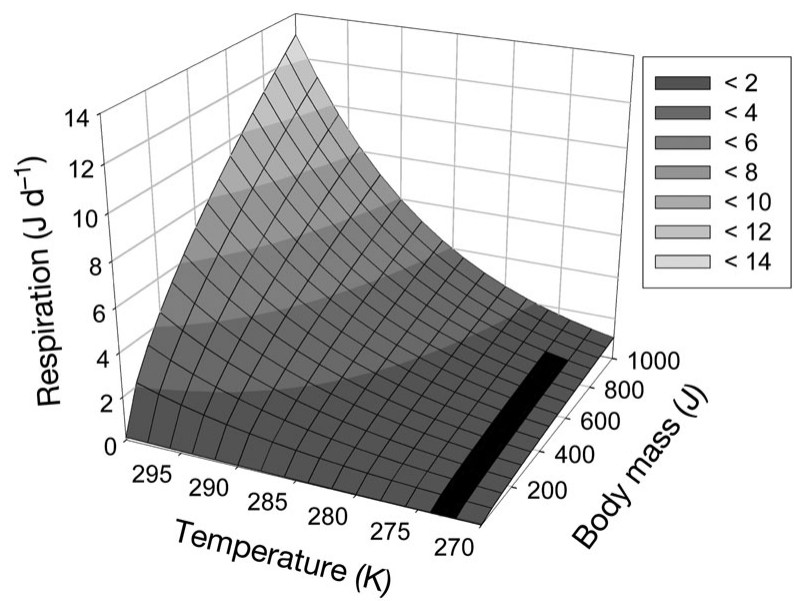

Fig. 1. Individual respiration $\left(R_{i} \mathrm{~J} \mathrm{~d}^{-1}\right)$ vs. body mass $\left(M_{i} \mathrm{~J}\right)$ and temperature $(T ; K)$ in chaetognaths according to the chaetognath respiration model: $\log (R)=10.0264+0.6643 \times$ $\log (M)-2957.8576 / T-0.3870 \times \log (D)+X_{\text {taxon }}$ (Eq. 7). Water depth $(D)$ is set to $500 \mathrm{~m}$ and taxon effects are neglected, i.e. $X_{\text {taxon }}=0$. Black area between 272 and $274 \mathrm{~K}$ : respiration rates to be expected for Southern Ocean chaetognaths at $500 \mathrm{~m}$ water depth

at low temperatures (e.g. $0^{\circ} \mathrm{C}$ or $273 \mathrm{~K}$ ) increase only slightly with higher body mass. In contrast, chaetognath respiration rates increase strongly at higher temperatures. The random distribution of residuals (Fig. 2) indicates that model accuracy is independent of respiration magnitude, i.e. the model has no obvious bias.

\section{Respiration, grazing upon copepods and indirect impact on primary production}

Respiration rates were similar during both seasons, accounting for $0.46 \mu \mathrm{g} \mathrm{C} \mathrm{m} \mathrm{C}^{-3}$ in summer and $0.54 \mu \mathrm{g} \mathrm{C} \mathrm{m}{ }^{-3} \mathrm{~d}^{-1}$ in winter between 500 and $2000 \mathrm{~m}$ depth (Table 3). Depth had a significant effect on chaetognath respiration (ANOVA, p $<0.001$ ). The highest rates were found in the 500 to $750 \mathrm{~m}$ layer. In the 2 strata below $1000 \mathrm{~m}$, the rates were the lowest, and the values did not differ significantly (ANOVA with Tukey's post hoc test, $\mathrm{p}>0.05$ ).

Table 5. Integrated annual respiration $(R)$ and corresponding annual carbon consumption $(Q)$, and annual net primary production $(P P)$ used by chaetognaths in the Southern Ocean. $\mathrm{N}=$ number of multinet stations

\begin{tabular}{|lcrcrc|}
\hline $\begin{array}{l}\text { Depth } \\
\text { range } \\
(\mathrm{m})\end{array}$ & $\mathrm{N}$ & $\begin{array}{c}R \\
\left(\mathrm{mg} \mathrm{C}^{-2} \mathrm{yr}^{-1}\right)\end{array}$ & $\begin{array}{c}Q \\
(\mathrm{mg} \mathrm{C} \\
\left.\mathrm{m}^{-2} \mathrm{yr}^{-1}\right)\end{array}$ & $\begin{array}{c}P P \\
\left(\mathrm{mg} \mathrm{C}^{-2} \mathrm{yr}^{-1}\right)\end{array}$ & $\begin{array}{c}P P \text { (with 50\% } \\
\text { carnivorous copepods; } \\
\left.\mathrm{mg} \mathrm{C} \mathrm{m}^{-2} \mathrm{yr}^{-1}\right)\end{array}$ \\
\hline $500-750$ & 43 & 112 & 225 & 749 & 1624 \\
$750-1000$ & 43 & 51 & 101 & 338 & 732 \\
$1000-1500$ & 42 & 64 & 128 & 426 & 924 \\
$1500-2000$ & 41 & 54 & 108 & 360 & 779 \\
$500-2000$ & 41 & 282 & 563 & 1877 & 4068 \\
\hline
\end{tabular}

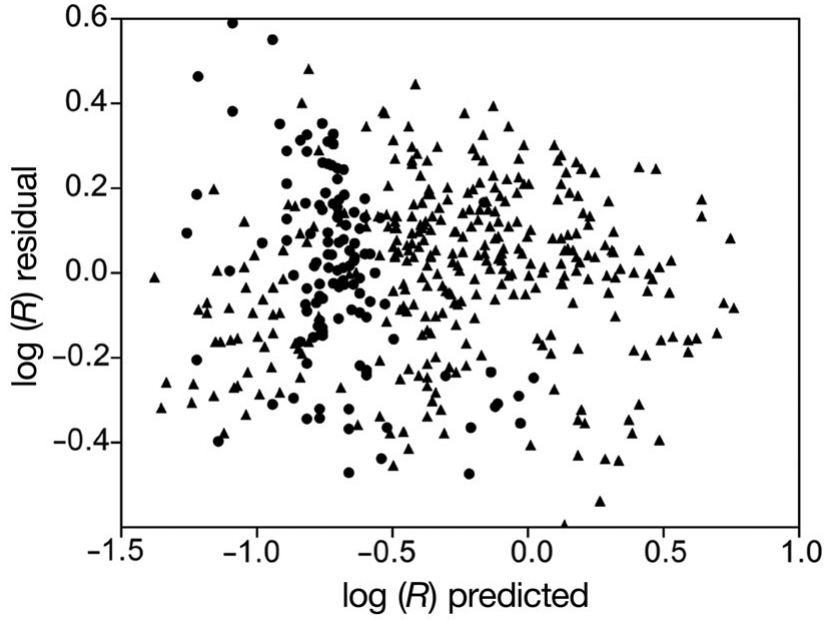

Fig. 2. Residual vs. estimated $\log (R)$ of the general chaetognath respiration model: $\log (R)=10.0264+0.6643 \times \log (M)-$ 2957.8576/T $-0.3870 \times \log (D)+X_{\text {taxon }}($ Eq. 7 ; see Fig. 1 for definitions). $\mathrm{N}=443, \mathrm{R}^{2}=0.832, \mathrm{p}<0.001 ; X_{\text {taxon }}=+0.1212$ for Eukrohniidae and -0.1212 for Sagittidae. $(\bullet)$ : Sagittidae;

(₫): Eukrohniidae

Annually, $282 \mathrm{mg} \mathrm{C} \mathrm{m} \mathrm{m}^{-2}$ are respired by chaetognaths in our investigated area, the highest rates of $112 \mathrm{mg} \mathrm{C} \mathrm{m}{ }^{-2} \mathrm{yr}^{-1}$ occurring between 500 and $750 \mathrm{~m}$ depth (Table 5). The corresponding chaetognath consumption is estimated to be $563 \mathrm{mg} \mathrm{C} \mathrm{m}^{-2} \mathrm{yr}^{-1}$, and the amount of primary production required to maintain this consumption through the copepod food link is about $1877 \mathrm{mg} \mathrm{C} \mathrm{m} \mathrm{yr}^{-1}$ (100\% herbivores) or $4068 \mathrm{mg} \mathrm{C} \mathrm{m}^{-2} \mathrm{yr}^{-1}$ (50\% herbivores and $50 \%$ carnivores). A $1 \%$ increase of carnivorous copepods in the diet requires about $2.3 \%$ more primary production.

\section{DISCUSSION}

\section{Chaetognath biomass distribution}

In the upper $300 \mathrm{~m}$ of the Atlantic sector of the Southern Ocean, chaetognaths comprise 5 to $30 \%$ of zooplankton abundance and biomass, with Eukrohnia hamata and Sagitta gazellae being the dominant species (Pakhomov et al. 2000). In our study area, this corresponds to a summer chaetognath biomass of up to $\sim 5000 \mu$ dry mass (DM) $\mathrm{m}^{-3}$ (Marginal Ice Zone; Pakhomov et al. 2000). Lower values (averages) are reported from the Weddell Sea $\left(\sim 580 \mu \mathrm{g} \mathrm{DM} \mathrm{m}^{-3}\right.$, 0-300 m, oceanic community; BoysenEnnen et al. 1991) and the Croker Passage $\left(<36 \mu g \mathrm{DM} \mathrm{m}^{-3}, 0-1000 \mathrm{~m}, E\right.$. hamata, S. gazellae and $S$. marri; Lancraft et al. 2004), but this variability 
may reflect geographical differences, year-to-year variability and sampling gear effects.

To obtain an estimate of average annual chaetognath biomass in the 0 to $500 \mathrm{~m}$ stratum of the Lazarev Sea, we used the data published by Ward et al. (1995) for South Georgia that are based on $200 \mu \mathrm{m}$ mesh sampling. These authors provided a vertical profile for chaetognaths in summer with a mean biomass of $\sim 2500 \mu \mathrm{g} \mathrm{DM} \mathrm{m}^{-3}$ for the upper $500 \mathrm{~m}$. The winter biomass in the upper water column is usually lower than in summer. Zooplankton volume data reported by Foxton (1956) for the upper $100 \mathrm{~m}$ indicate higher values by a factor of $\sim 3$ in summer than in winter in the Antarctic. The mean zooplankton volume in the 0 to $1000 \mathrm{~m}$ layer at these latitudes was nearly the same during both seasons (Foxton 1956). Based on Foxton's information, we assume the summer chaetognath biomass to be higher by a factor of 2 compared to winter in the 0 to $500 \mathrm{~m}$ layer, which results in chaetognath biomass estimates of $2500 \mu \mathrm{g} \mathrm{DM} \mathrm{m}{ }^{-3}$ for summer and $1250 \mu \mathrm{g} \mathrm{DM} \mathrm{m}{ }^{-3}$ for winter. Hence, annual average biomass in the 0 to $500 \mathrm{~m}$ layer is $1875 \mu \mathrm{g} \mathrm{DM} \mathrm{m}^{-3}$, corresponding to $619 \mu \mathrm{g} \mathrm{C} \mathrm{m}^{-3}$ (average $\mathrm{C} / \mathrm{DM}=0.33$, Table 2). In the 500 to $2000 \mathrm{~m}$ range, we measured $133 \mu \mathrm{g} \mathrm{m}^{-3}$ (annual mean, Table 3). Integrated across the water column, chaetognath biomass amounts to $\sim 309 \mathrm{mg} \mathrm{C} \mathrm{m}^{-2}$ in the $0-500 \mathrm{~m}$ range and to $200 \mathrm{mg} \mathrm{C}$ $\mathrm{m}^{-2}$ in the $500-2000 \mathrm{~m}$ range. Therefore, $39 \%$ of total chaetognath biomass is situated in the meso- and bathypelagic realm. We assume a corresponding depth distribution of chaetognath metabolic activity (see 'Chaetognath energy budget').

Within the meso-/bathypelagic region, chaetognath biomass decreases with depth. The biomass is higher in winter than in summer (Table 3). In the 500 to $750 \mathrm{~m}$ layer, where the abundance was lower in winter, the higher biomass results from the presence of larger and more developed Eukrohnia hamata (Kruse et al. 2009).

The fraction of total midwater zooplankton in the Southern Ocean that represent chaetognaths can only be estimated. We know that copepod biomass decreases from epipelagic layers to $1000 \mathrm{~m}$ in summer (Schnack-Schiel et al. 1998) and probably continues to decrease towards bathypelagic depths. However, reliable quantitative data on copepods and other zooplankton below $1000 \mathrm{~m}$ are rare for the Southern Ocean.

\section{Chaetognath respiration}

Our respiration model (Fig. 1) represents an unbiased predictor of chaetognath metabolic rate, with an accuracy that is comparable to other models with similar taxonomic resolution (e.g. Warwick \& Price 1979, Larson 1987, Clarke \& Johnston 1999, Seibel
2007). Of concern, however, is the distinctly negative effect of water depth on respiration in our model (Eq. 7). A negative effect of depth on mass specific respiration has been observed in several taxa across a much wider depth range, e.g. Torres et al. (1979), Childress et al. (1990), Thuesen \& Childress (1993). Regarding our model, it remains unclear whether this is a residual temperature effect (Thuesen \& Childress 1993), a true physiological adaptation (Drazen \& Seibel 2007), or just an artifact. For instance, Kruse et al. (2010) did not find a significant depth effect on respiration rates of Eukrohnia hamata and E. bathypelagica, although rates were measured at normal surface pressure. The relationship between respiration and depth remains a topic of debate. One party reported a decline in copepod respiration with depth (Ikeda et al. 2006, Ikeda 2008), whereas other findings support the absence of large depth-related declines in species without image-forming eyes (Childress \& Thuesen 1992, Childress et al. 2008). It is possible that the apparent depth effect in our chaetognath model may mask effects of the interplay between species-specific depth distribution and species-specific size range. Thus, the model provides a reasonable estimate of respiration rate for chaetognaths in general, but not for a distinct species.

Physical, chemical and biological parameters like pressure, oxygen concentration, $\mathrm{pH}$ and food may influence respiration rates as well (Hernández-León \& Ikeda 2005). However, zooplankton species react differently to these factors, some of which have been shown to be negligible for chaetognaths. Experiments at 0.101 and $10.1 \mathrm{MPa}$ (equivalent to 0 and $1000 \mathrm{~m}$ depth) have shown, for example, that hydrostatic pressure has no significant effect on oxygen consumption rates of chaetognaths (Childress \& Thuesen 1993). Therefore, pressure was not included in the respiration experiments or in the model. Respiration rates are also influenced by the percentage of oxygen saturation. Generally, a saturation of 70 to $80 \%$ is suggested as a limit above which the zooplankton respiration is little affected by the oxygen concentration (with few exceptions, Ikeda 1977a). Low oxygen concentrations, associated with the oxygen minimum layer for example, might influence chaetognath respiration rates, however. In addition, the pH may decrease in this layer. Chaetognaths are sensitive to a lowered $\mathrm{pH}$ (Yamada \& Ikeda 1999). To our knowledge, no studies have evaluated the effect of $\mathrm{pH}$ changes on respiration of chaetognaths; thus it was not possible to include this parameter in our model. Furthermore, respiration rates are significantly influenced by feeding conditions (Ikeda et al. 2000). The rates are usually lower in starved animals than in non-starved animals (e.g. Ikeda 1977b, Brey 2010); accordingly, oxygen con- 
sumption rates and ingestion rates are often positively correlated. However, the influence of feeding on zooplankton metabolism is rather complex and may be affected, amongst other things, by different kinds of prey and species-specific differences in nutritional and metabolic status of predators (Ikeda et al. 2000). In addition, bacterial activity during chaetognath experiments might also overstate measured animal oxygen consumption. We consider this effect to be negligible in our experiments due to prefiltration of water, unfed chaetognaths and hence low excretion. Considering the complexity of the various interacting factors, the presented model, even if simplified, yields the best approximation at present.

\section{Chaetognath energy budget}

It is well established that copepods are the principal food source of chaetognaths. In the Antarctic chaetognaths Eukrohnia hamata and Sagitta gazellae, copepods constitute $\sim 96$ and $58 \%$ of the diet (Froneman et al. 1998), and in the meso- and bathypelagic S. zetesios they account for $72 \%$ (North Pacific and Sagami Bay, Japan, Terazaki \& Marumo 1982). Other zooplankton, including ostracods, appendicularians and even chaetognaths themselves, usually represent a smaller percentage of the chaetognath diet. Hence, assuming that copepods are the only source of food is a reasonable simplification for a first attempt to establish a chaetognath community energy budget.

What is the actual impact of midwater chaetognaths on copepod population dynamics? Copepod integrated biomass amounts to $3150 \mathrm{mg} \mathrm{C} \mathrm{m}^{-2}$ for the $500-2000 \mathrm{~m}$ depth range in summer (derived from the data of Schnack-Schiel et al. 1998 for 0-1000 m), and the corresponding copepod production in this season is $\sim 157.5 \mathrm{mg} \mathrm{C} \mathrm{m}^{-2} \mathrm{~d}^{-1}$, assuming a daily production rate of $5 \%$ (Voronina 1984 in Froneman et al. 1998) and a uniform copepod size composition. Thus, the predation by meso- and bathypelagic chaetognaths of $1.5 \mathrm{mg} \mathrm{C} \mathrm{m}^{-2}$ $\mathrm{d}^{-1}$, estimated in our study (563/365, Table 5), corresponds to $0.05 \%$ of the copepod standing stock per day in summer, or to $0.98 \%$ of copepod daily production.

These estimates are conservative for 2 reasons. On the one hand, metabolism and hence energy demand of free-living chaetognaths may be higher than in the restraining conditions of respiration measurement vessels. Previous studies have shown, for instance, that active metabolism oxygen consumption is nearly twice as high in crustaceans (Vinberg 1950). On the other hand, by integrating down to $2000 \mathrm{~m}$ water depth, we overestimate the copepod biomass at depth. Less than $5 \%$ of the copepod biomass between 0 and $1000 \mathrm{~m}$ depth is located below $300 \mathrm{~m}$ in summer (Schnack-
Schiel et al. 1998). Therefore, predation impact may be considerably higher on the part of the copepod community that is accessible to meso- and bathypelagic chaetognaths and may attain magnitudes comparable to values reported for the epipelagic realm. Published values for Antarctic chaetognath daily consumption in the upper pelagic zone range between 0 and $5.2 \%$ of the copepod standing stock for Eukrohnia hamata and between 0 and $3.2 \%$ for Sagitta gazellae (Øresland 1990, 1995, Froneman \& Pakhomov 1998, Froneman et al. 1998). This corresponds to up to $103 \%$ of the daily copepod production in number for E. hamata and up to $63 \%$ for S. gazellae (Froneman \& Pakhomov 1998, Froneman et al. 1998).

The winter conditions at meso- and bathypelagic depths might be different. In winter, the number of copepods increases at greater depths due to seasonal downward migration (e.g. Schnack-Schiel \& Hagen 1994, Atkinson \& Sinclair 2000), and their production rate is probably much lower at this time of the year (1\% daily production rate, Voronina 1984 in Froneman et al. 1998). Chaetognaths also exhibit seasonal vertical migrations (David 1958, Kruse et al. 2009). If chaetognaths feed throughout the year, as we assume (Hagen 1999, Kruse et al. 2010), they may have a higher predation impact on the copepod standing stock in winter than in summer.

On an annual basis, $1.9 \mathrm{~g} \mathrm{C} \mathrm{m}^{-2} \mathrm{yr}^{-1}$ of primary production is required to maintain the midwater chaetognath community via herbivorous copepods, corresponding to $\sim 2.8 \%$ of net primary production $(67 \mathrm{~g} \mathrm{C}$ $\mathrm{m}^{-2} \mathrm{yr}^{-1}$ integrated over the upper $100 \mathrm{~m}$ in the pelagic province of the Weddell Sea, Arrigo et al. 2008). If chaetognaths also feed on carnivorous copepods, such as Euchaeta spp. (Hopkins 1985, Øresland 1990), the required primary production may significantly increase. Assuming carnivorous copepods to comprise $50 \%$ of the diet, the required primary production increases to $4.1 \mathrm{~g} \mathrm{C} \mathrm{m}^{-2} \mathrm{yr}^{-1}$ or $6.1 \%$. Even if the actual contribution of carnivorous copepods to the diet is between 0 and $50 \%$, chaetognaths may play a significant role as consumers in the ecosystem. For the whole water column, chaetognath consumption amounts to $1.4 \mathrm{~g} \mathrm{C} \mathrm{m}^{-2} \mathrm{yr}^{-1}$, if we scale up these budget calculations by applying a biomass factor of 1.5 for the upper $500 \mathrm{~m}$ (albeit neglecting the depth effect on respiration). The primary production required to fuel this consumption through the copepod food chain is between $4.8 \mathrm{~g} \mathrm{C} \mathrm{m}^{-2} \mathrm{yr}^{-1}$ (100\% herbivorous prey) and $10.4 \mathrm{~g} \mathrm{C}$ $\mathrm{m}^{-2} \mathrm{yr}^{-1}$ (50\% carnivorous prey), corresponding to 7.1 and $15.5 \%$ of the annual net primary production, respectively.

Chaetognaths themselves may also represent an important prey for higher trophic levels. Assuming chaetognath production to be $30 \%$ of their consump- 
tion, $0.17 \mathrm{~g} \mathrm{C} \mathrm{m}^{-2} \mathrm{yr}^{-1}$ is available for their predators, e.g. amphipods and myctophid fish (Hopkins 1985, Hopkins \& Torres 1989, Perissinotto \& McQuaid 1992, Pakhomov et al. 1996), between 500 and $2000 \mathrm{~m}$. Our findings, therefore, support the view that the mesopelagic zooplankton in Antarctic waters play a significant role in energy transfer from primary production to higher trophic levels.

Acknowledgements. We thank the captains and the crew of RV 'Polarstern' for their skilful support. We also thank C. Lorenzen and S. Murawski, who helped with the carbon analyses. Special thanks go to R. Waggett and P. A. Teste, who provided respiration data for Sagitta tenuis. Comments on the manuscript by 4 anonymous reviewers were greatly appreciated. This publication is part of the doctoral thesis of S.K.

\section{LITERATURE CITED}

Arrigo KR, Van Dijken GL, Bushinsky S (2008) Primary production in the Southern Ocean, 1997-2006. J Geophys Res 113:C08004. doi:10.1029/2007JC004551

Atkinson A, Sinclair JD (2000) Zonal distribution and seasonal vertical migration of copepod assemblages in the Scotia Sea. Polar Biol 23:46-58

Båmstedt U (1979) Seasonal variation in the respiratory rate and ETS activity of deep-water zooplankton from the Swedish West coast. In: Naylor E, Hartnoll RG (eds) Cyclic phenomena in marine plants and animals. Proc 13th Eur Mar Biol Symp, Pergamon Press, Oxford, p 267-274

Barnett V, Price T (1995) Outliers in statistical data, 3rd edn. Wiley \& Sons, New York, NY

Boysen-Ennen E, Hagen W, Hubold G, Piatkowski U (1991) Zooplankton biomass in the ice-covered Weddell Sea, Antarctica. Mar Biol 111:227-235

Brey T (2001) Population dynamics in benthic invertebrates. A virtual handbook. Version 01.2 available at www. thomas-brey.de/science/virtualhandbook

Brey T (2010) An empirical model for estimating aquatic invertebrate respiration. Meth Ecol Evol 1:92-101

Brey T, Müller-Wiegmann C, Zittier Z, Hagen W (2010) Body composition in aquatic organisms: a global data bank of relationships between mass, element composition and energy content. J Sea Res doi:10.1016/j.seares.2010.05.002

Casanova JP (1985) Description de l'appareil génital primitif du genre Heterokrohnia et nouvelle classification des Chaetognathes. C R Acad Sci Paris 301(III):397-402

Childress JJ, Thuesen EV (1992) Metabolic potential of deepsea animals: regional and global scales. In: Rowe GT, Pariente V (eds) Deep-sea food chains and the global carbon cycle. Kluwer Academic Publishers, Dordrecht, p 217-236

Childress JJ, Thuesen EV (1993) Effects of hydrostatic pressure on metabolic rates of six species of deep-sea gelatinous zooplankton. Limnol Oceanogr 38:665-670

Childress JJ, Cowles DL, Favuzzi JA, Mickel TJ (1990) Metabolic rates of benthic deep-sea decapod crustaceans decline with increasing depth primarily due to the decline in temperature. Deep-Sea Res 37:929-949

> Childress JJ, Seibel BA, Thuesen EV (2008) N-specific metabolic data are not relevant to the 'visual interactions' hypothesis concerning the depth-related declines in metabolic rates: Comment on Ikeda et al. (2006). Mar Ecol Prog Ser 373:187-191

Clarke A, Johnston NM (1999) Scaling of metabolic rate with body mass and temperature in teleost fish. J Anim Ecol 68:893-905

Cosper TC, Reeve MR (1975) Digestive efficiency of the chaetognath Sagitta hispida Conant. J Exp Mar Biol Ecol 17: $33-38$

Coston-Clements L, Waggett RJ, Tester PA (2009) Chaetognaths of the United States South Atlantic Bight: distribution, abundance and potential interactions with newly spawned larval fish. J Exp Mar Biol Ecol 373:111-123

David PM (1958) The distribution of the Chaetognatha of the Southern Ocean. Discovery Rep 29:199-228

Drazen JC, Seibel BA (2007) Depth-related trends in metabolism of benthic and benthopelagic deep-sea fishes. Limnol Oceanogr 52:2306-2316

Duró A, Sabatés A, Gili JM (1999) Mesoscale spatial distribution of chaetognaths along hydrographic gradients in the South Scotia Sea (Antarctica). Polar Biol 22:195-206

Falkenhaug T (1991) Prey composition and feeding rate of Sagitta elegans var. arctica (Chaetognatha) in the Barents Sea in early summer. Polar Res 10:487-506

Foxton P (1956) The distribution of the standing crop of zooplankton in the Southern Ocean. Discovery Rep 28:191-236

- Froneman PW, Pakhomov EA (1998) Trophic importance of the chaetognaths Eukrohnia hamata and Sagitta gazellae in the pelagic system of the Prince Edward Islands (Southern Ocean). Polar Biol 19:242-249

Froneman PW, Pakhomov EA, Perissinotto R, Meaton V (1998) Feeding and predation impact of two chaetognath species, Eukrohnia hamata and Sagitta gazellae, in the vicinity of Marion Island (Southern Ocean). Mar Biol 131:95-101

Giesecke R, González HE (2004) Feeding of Sagitta enflata and vertical distribution of chaetognaths in relation to low oxygen concentrations. J Plankton Res 26:475-486

> Giesecke R, González HE, Bathmann U (2010) The role of the chaetognath Sagitta gazellae in the vertical carbon flux of the Southern Ocean. Polar Biol 33:293-304

Hagen W (1985) On distribution and population structure of Antarctic Chaetognatha. Meeresforsch 30:280-291

Hagen W (1999) Reproductive strategies and energetic adaptations of polar zooplankton. Invertebr Reprod Dev 36: $25-34$

Hernández-León S, Ikeda T (2005) Zooplankton respiration. In: del Giorgio PA, Williams PJ le B (eds) Respiration in aquatic ecosystems. Oxford University Press, Oxford, p 57-82

Hopkins TL (1985) Food web of an Antarctic midwater ecosystem. Mar Biol 89:197-212

> Hopkins TL, Torres JJ (1989) Midwater food web in the vicinity of a marginal ice zone in the western Weddell Sea. Deep-Sea Res 36:543-560

Ikeda T (1977a) The effect of laboratory conditions on the extrapolation of experimental measurements to the ecology of marine zooplankton. II. Effect of oxygen saturation on the respiration rate. Bull Plankton Soc Japan 24:19-28

Ikeda T (1977b) The effect of laboratory conditions on the extrapolation of experimental measurements to the ecology of marine zooplankton. IV. Changes in respiration and excretion rates of boreal zooplankton species maintained under fed and starved conditions. Mar Biol 41:241-252

> Ikeda T (1989) Are Antarctic zooplankton metabolically more cold-adapted than Arctic zooplankton? An intra-generic comparison of oxygen consumption rates. J Plankton Res 11:619-624

- Ikeda T (2008) Metabolism in mesopelagic and bathypelagic copepods: Reply to Childress et al. (2008). Mar Ecol Prog Ser 373:193-198

Ikeda T, Hirakawa K (1998) Metabolism and body composition of zooplankton in the cold mesopelagic zone of the 
southern Japan Sea. Plankton Biol Ecol 45:31-44

Ikeda T, Kirkwood R (1989) Metabolism and elemental composition of a giant chaetognath Sagitta gazellae from the Southern Ocean. Mar Biol 100:261-267

Ikeda T, Skjoldal HR (1989) Metabolism and elemental composition of zooplankton from the Barents Sea during early Arctic summer. Mar Biol 100:173-183

Ikeda T, Torres JJ, Hernández-León S, Geiger SP (2000) Metabolism. In: Harris RP, Wiebe PH, Lenz J, Skjoldal HR, Huntley M (eds) ICES zooplankton methodological manual. Academic Press, San Diego, CA, p 455-532

Ikeda T, Sano F, Yamaguchi A, Matsuishi T (2006) Metabolism of mesopelagic and bathypelagic copepods in the western North Pacific Ocean. Mar Ecol Prog Ser 322: $199-211$

Ivleva IV (1976) The rate of oxygen consumption by the Atlantic Chaetognatha. Biol Morja Kiev 39:3-11

Johnson TB, Terazaki M (2004) Chaetognath ecology in relation to hydrographic conditions in the Australian sector of the Antarctic Ocean. Polar Biosci 17:1-15

Kruse S, Bathmann U, Brey T (2009) Meso- and bathypelagic distribution and abundance of chaetognaths in the Atlantic sector of the Southern Ocean. Polar Biol 32: $1359-1376$

Kruse S, Hagen W, Bathmann U (2010) Feeding ecology and energetics of the Antarctic chaetognaths Eukrohnia hamata, E. bathypelagica and E. bathyantarctica. Mar Biol 157:2289-2302

- Lancraft TM, Reisenbichler KR, Robison BH, Hopkins TL, Torres JJ (2004) A krill-dominated micronekton and macrozooplankton community in Croker Passage, Antarctica with an estimate of fish predation. Deep-Sea Res II 51: $2247-2260$

Landry MR, Calbet A (2004) Microzooplankton production in the oceans. ICES J Mar Sci 61:501-507

Larson RJ (1987) Respiration and carbon turnover rates of medusae from the NE Pacific. Comp Biochem Physiol 87A: 93-100

> Nagasawa S (1985) The digestive efficiency of the chaetognath Sagitta crassa Tokioka, with observations on the feeding process. J Exp Mar Biol Ecol 87:271-281

Nival P, Nival S, Palazzoli I (1972) Données sur la respiration de différents organismes communs dans le plancton de Villefranche-sur-Mer. Mar Biol 17:63-76

Øresland V (1987) Feeding of the chaetognaths Sagitta elegans and $S$. setosa at different seasons in Gullmarsfjorden, Sweden. Mar Ecol Prog Ser 39:69-79

> Øresland V (1990) Feeding and predation impact of the chaetognath Eukrohnia hamata in Gerlache Strait, Antarctic Peninsula. Mar Ecol Prog Ser 63:201-209

Øresland V (1995) Winter population structure and feeding of the chaetognath Eukrohnia hamata and the copepod Euchaeta antarctica in Gerlache Strait, Antarctic Peninsula. Mar Ecol Prog Ser 119:77-86

Pakhomov EA, Perissinotto R, McQuaid CD (1996) Prey composition and daily rations of myctophid fishes in the Southern Ocean. Mar Ecol Prog Ser 134:1-14

Pakhomov EA, Perissinotto R, Froneman PW (1999) Predation impact of carnivorous macrozooplankton and micronekton in the Atlantic sector of the Southern Ocean. J Mar Syst 19:47-64

Pakhomov EA, Perissinotto R, McQuaid CD, Froneman PW (2000) Zooplankton structure and grazing in the Atlantic sector of the Southern Ocean in late austral summer 1993. Part 1. Ecological zonation. Deep-Sea Res I 47:1663-1686

Perissinotto R, McQuaid CD (1992) Land-based predator impact on vertically migrating zooplankton and micro- nekton advected to a Southern Ocean archipelago. Mar Ecol Prog Ser 80:15-27

Reeve MR (1970) The biology of Chaetognatha I. Quantitative aspects of growth and egg production in Sagitta hispida. In: Steele JH (ed) Marine food chains. Oliver \& Boyd, Edinburgh, p 168-189

- Reeve MR, Raymont JEG, Raymont JKB (1970) Seasonal biochemical composition and energy sources of Sagitta hispida. Mar Biol 6:357-364

Salonen K, Sarvala J, Hakala I, Viljanen ML (1976) The relation of energy and organic carbon in aquatic invertebrates. Limnol Oceanogr 21:724-730

Sameoto DD (1972) Yearly respiration rate and estimated energy budget for Sagitta elegans. J Fish Res Board Can 29: 987-996

Sameoto DD (1987) Vertical distribution and ecological significance of chaetognaths in the Arctic environment of Baffin Bay. Polar Biol 7:317-328

Schnack-Schiel SB, Hagen W (1994) Life cycle strategies and seasonal variations in distribution and population structure of four dominant calanoid copepod species in the eastern Weddell Sea, Antarctica. J Plankton Res 16: 1543-1566

> Schnack-Schiel SB, Hagen W, Mizdalski E (1998) Seasonal carbon distribution of copepods in the eastern Weddell Sea, Antarctica. J Mar Syst 17:305-311

Seibel BA (2007) On the depth and scale of metabolic rate variation: scaling of oxygen consumption rates and enzymatic activity in the Class Cephalopoda (Mollusca). J Exp Biol 210: 1-11

Sokal RR, Rohlf FJ (1981) Biometry. The principles and practice of statistics in biological research, 2 nd edn. W.H. Freeman, San Francisco, CA

Straile D (1997) Gross growth efficiencies of protozoan and metazoan zooplankton and their dependence on food concentration, predator-prey weight ratio, and taxonomic group. Limnol Oceanogr 42:1375-1385

Terazaki M (1989) Distribution of chaetognaths in the Australian sector of the Southern Ocean during the Biomass Sibex cruise (KH-83-4). Proc NIPR Symp Polar Biol 2: $51-60$

Terazaki M, Marumo R (1982) Feeding habits of meso- and bathypelagic chaetognatha, Sagitta zetesios Fowler. Oceanol Acta 5:461-464

> Thuesen EV, Childress JJ (1993) Enzymatic activities and metabolic rates of pelagic chaetognaths: lack of depthrelated declines. Limnol Oceanogr 38:935-948

Torres JJ, Belman BW, Childress JJ (1979) Oxygen consumption rates of midwater fishes as a function of depth of occurrence. Deep-Sea Res 26A:185-197

Vinberg GG (1950) Metabolism and size in crustaceans. Russ J Gen Biol 11:367-380 (in Russian)

Voronina NM (1984) Pelagic ecosystems of the Southern Ocean. Nauka Press, Moscow (in Russian)

Ward P, Atkinson A, Murray AWA, Wood AG, Williams R, Poulet SA (1995) The summer zooplankton community at South Georgia: biomass, vertical migration and grazing. Polar Biol 15:195-208

Warwick RM, Price R (1979) Ecological and metabolic studies on free-living nematodes from an estuarine mud-flat. Estuar Coast Mar Sci 9:257-271

Welch HE, Siferd TD, Bruecker P (1996) Population densities, growth, and respiration of the chaetognath Parasagitta elegans in the Canadian high Arctic. Can J Fish Aquat Sci 53:520-527

Yamada Y, Ikeda T (1999) Acute toxicity of lowered pH to some oceanic zooplankton. Plankton Biol Ecol 46:62-67 